\title{
Usage of glulam waste for particleboard production
}

Uso de resíduos de MLC para produção de painéis de partículas

\section{Tiago Hendrigo de Almeida Fabiane Salles Ferro Diego Henrique de Almeida Francisco Antonio Rocco Lahr}

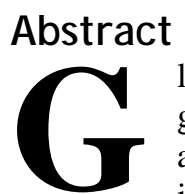

lulam are long engineered wood beams (or columns) composed by graded lumbers bounded together with the use of appropriate adhesives under pre-established pressure. The greater the industrialization the greater will be the production of wood waste a matter that deserves attention and development of technologies in terms of its waste management. This paper aimed to investigate the technical feasibility of Brazilian industrial glulam waste usage as raw material for particleboard production industries using a castor oil-based polyurethane adhesive. Particleboards were manufactured using glulam (produced with Eucalyptus urograndis) waste particles and castor oil-based polyurethane adhesive at 8, 10, 12 and 14\% mass proportions and characterized based on NBR 14810-2:2006 procedures. Analysis of variance was performed for the comparison of mechanical and physical performances of the panels. The increase of adhesive content caused and increase of the MOR (Rupture Modulus), but the MOE (Elasticity Modulus) and the physical properties remained unaltered above $12 \%$ of adhesive content. The adhesive content greater than $8 \%$ provided panel performances that met the standardized specifications. Based on these findings, it was possible to conclude that the waste of glulam produced with Eucalyptus urograndis can be used as raw material for particleboard production.

Keywords: Glulam. Particleboards. Technical feasibility. Waste management.

\section{Resumo}

Madeira Lamelada Colada (MLC) podem ser empregadas como vigas ou colunas. A MLC é um produto engenheirado de madeira composto por lamelas classificadas e coladas usando adesivos apropriados e pressão preestabelecida.

${ }^{1}$ Tiago Hendrigo de Almeida ${ }^{1}$ Universidade de São Paulo São Carlos - SP - Brasil

${ }^{2}$ Fabiane Salles Ferro ${ }^{2}$ Universidade Estadual do CentroIrati - PR - Brasil

${ }^{3}$ Diego Henrique de Almeida ${ }^{3}$ Universidade Federal de Rondônia Porto Velho - RO - Brasil

${ }^{4}$ Francisco Antonio Rocco Lahr ${ }^{4}$ Universidade de São Paulo São Carlos - SP - Brasil

Recebido em 26/03/19

Aceito em 09/09/19
Quanto maior a industrialização do processo de fabricação de MLC maior é a geração de resíduos, que merecem atenção, e o desenvolvimento de tecnologias para a agreagação de valor nestes. O objetivo deste trabalho foi investigar a viabilidade técnica do uso do resíduo industrial brasileiro da produção de MLC como matéria-prima para a indústria de painéis de partículas utilizando adesivo poliuretano à base de óleo de mamona. Painéis de partículas foram produzidos utilizando resíduos da produção de MLC (produzida com Eucalyptus urograndis) e resina poliuretana à base de mamona na proporção em massa de 8, 10, 12 e $14 \%$ e caracterizados de acordo com os procedimentos do documento normativo NBR 14810-2:2006. Análise de variância foi realizada para comparação dos desempenhos físicos e mecânicos dos painéis. O aumento do teor de adesivo provocou aumento de MOR (Módulo de ruptura), mas o MOE (Módulo de Elasticidade) e as propriedades físicas se mantiveram constantes acima de 12\% de adesivo. Painéis com teores de adesivo maiores que $8 \%$ apresentaram desempenhos que atenderam os requisitos normativos. Assim, foi possível concluir que os resíduos de MLC produzida com Eucalyptus urograndis podem ser utilizados como matéria-prima para produção de painéis de partículas.

Palavras-chave: MLC. Painéis de partículas. Viabilidade técnica. Gestão de resíduos. 


\section{Introduction}

Glued laminated timber (Glulam) is an engineered wood product that has been widely used in countries with great experience in the construction of timber structures such as USA, Canada and Germany (FOREST..., 1999; ZHOU; ZHU; TORATTI, 2009). The glulam product consists of long engineered wood beams (or columns) composed by graded lumbers bound together through the use of appropriate adhesives under preestablished pressure (ICIMOTO, 2018; SEGUNDINHO et al., 2014). Glulam is produced in specialized industries undergoing high quality control and a well-established manufacturing process, in order to provide the best performance of the finished product (ALMEIDA et al., 2014; ICIMOTO et al., 2016; MIRZAEI; MOHEBBY; EBRAHIMI, 2017).

The industrialization process provides a greater quality and lower cost for several wood-based products, and also makes the use of these technologies more extensive (OSMANNEZHAD; FAEZIPOUR; EBRAJIMI, 2014). However, as a consequence, the greater the industrialization, greater will be the production of wood waste, a matter which deserves attention and development of technologies for waste management through the reduction of the waste or by using the rejects as raw material in another segment for waste valorization (OGUNWUSI, 2014; ALMEIDA et al., 2017).

In order to produce glulam beams, several wood machining activities are performed, from the wood harvesting, to sawmill and lumber grading, where the production of wood waste already begins. After the glulam pressing procedure these engineered wood beams undergo a finishing machine process that produces glued wood waste which may be more toxic because of the use of a chemical adhesive (mainly polyurethanebased).

Wood-based panels such as particleboards are alternatives for wood waste valorization, because they are basically a composite produced with wood particles (usually Eucalyptus sp. and Pinus sp. wood coming from reforested areas), and a polymeric matrix, usually Formaldehyde-based adhesive (IWAKIRI, 2005; ALVES et al., 2014; NASCIMENTO et al., 2013). It is important to highlight that the adhesive constitutes the major final cost component of particleboard panels (MENDES et al., 2010). Wood panels are mainly used in furniture and construction sectors, and about a half of the wood panel production is Medium Density Particleboard (MDP). MDP is mostly used in the furniture production and instance wood floors (BIAZUS; HORA; LEITE, 2010).

Urea-formaldehyde is the most used adhesive for particleboard industrial production, presenting low cost, high curing velocity and fire integrity (LESSMANN, 2008). However, the high emission of formaldehyde in the pressing activity reinforces the need to develop new technologies for wood adhesives (FIORELLI et al., 2014).

The castor oil-based polyurethane resin is an alternative to formaldehyde-based adhesives. This is a bicomponent resin, composed by a polyol and a prepolymer (FERRO et al., 2014). This alternative resin does not require the paraffin emulsion utilization, which is a positive point of this adhesive utilization (NASCIMENTO et al., 2013).

Particleboard performance evaluation is based on NBR 14810-3 (ABNT, 2006a) "Wood Particleboards - Tests Procedures", which prescribes the physical and mechanical tests for determining the following panel properties: Density, Modulus of Elasticity and Modulus of Rupture in Static bending test, Internal Adhesion - Perpendicular tension stress, Thickness Swelling in 2 and 24 hours, Water absorption in 2 and 24 hours, Edge Screw Pullout and Face Screw Pullout. NBR 14810-2 (ABNT, 2006b) "Wood Particleboards Requirements” establishes the reference performance values.

This paper aimed to investigate the technical feasibility of Brazilian industrial glulam waste usage as raw material for the particleboard production industries, based on NBR 14810-3 (ABNT, 2006a) "Wood Particleboards - Tests Procedures” specifications for physical and mechanical performances and using castor oil-based polyurethane resin.

\section{Materials and methods}

The waste of Brazilian industrial glulam produced with Eucalyptus urograndis (a hybrid of Eucalyptus urophylla and Eucalyptus grandis) and polyurethane adhesive (Figure 1), was used for the particleboard production in this investigation. The glulam waste was processed in a knife mill for production of particles. For particle adhesion the castor oil-based polyurethane resin (an alternative resin to the formaldehyde-based adhesives) was used in four mass ratios of adhesive/particles. Table 1 presents these compositions. 
Figure 1 - Glulam in the static bending test

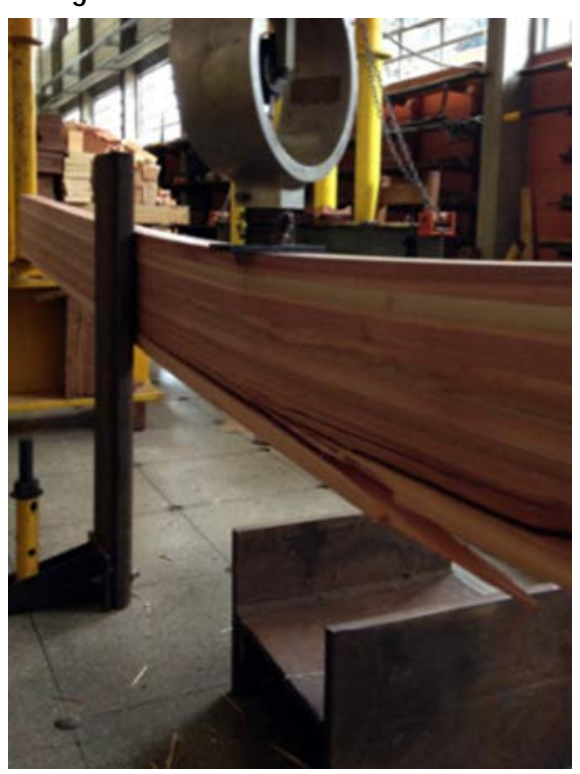

Table 1 - Compositions of the produced panels

\begin{tabular}{c|c|c}
\hline Compositions & Mass ratio of adhesive/wood particles & Number of panels \\
\hline C1 & $8 \%$ & 3 \\
C2 & $10 \%$ & 3 \\
C3 & $12 \%$ & 3 \\
C4 & $14 \%$ & 3 \\
\hline
\end{tabular}

Three panels were produced for each composition (C1 to C4 varying the adhesive content) totaling 12 panels. Figure 2 illustrates the particleboard manufacturing process, Figure 2a presents a panel press device and Figure $2 \mathrm{~b}$ the final panel produced.

The final dimensions of the panels produced were $300 \mathrm{~mm}$ x $300 \mathrm{~mm}$ and they were tested for physical and mechanical performances according to NBR 14810-2 (ABNT, 2006b) and NBR 14810-3 (ABNT, 2006a) Brazilian codes. Polyol/pre-polymer considered a mass ratio equal to 1 . Panels were pressed at $100^{\circ} \mathrm{C}$, for 10 minutes and 4MPa.

The following panel properties were determined: Density $\left(\mathrm{g} / \mathrm{cm}^{3}\right)$, Modulus of Elasticity (MOE) and Modulus of Rupture (MOR) in Static bending test (MPa), Internal Adhesion (MPa), Thickness Swelling in 2 and 24 hours (\%), Water absorption in 2 and 24 hours (\%), Edge Screw Pullout (N) and Face Screw Pullout (N).

Each panel provided five specimens for static bending tests, five specimens for Internal Adhesion tests, five specimens for Thickness Swelling tests in 2 and 24 hours, five specimens for Water absorption tests in 2 and 24 hours, five specimens for Edge Screw Pullout tests and five specimens for Face Screw Pullout tests. The entire physical and mechanical characterization of particleboards provided 600 determinations.

The statistical analysis was performed using the software R version 3.5.2. Analysis of variance (ANOVA) was performed at $5 \%$ significance level for evaluation of the equivalence among groups (four treatments considered - for each panel property investigated). For ANOVA validation, the Shapiro-Wilk normality tests (SW) and Bartlett's homogeneity of variances tests (Bt) were performed at the same significance level. When the non-normality of the distribution of the data was proven the logarithmic transformation was performed. The comparisons of the particleboards' properties with significant p-value of ANOVA were tested through Tukey's contrast test. Summary of results were made for their best presentation, as well as boxplot charts.

\section{Results and discussions}

The performances of the panels were determined through the conduction of physical and mechanical tests. Tables 2 to 6 present the summary of results for Modulus of Elasticity (MOE), Modulus of Rupture (MOR), Density, Thickness Swelling in 2h, Thickness Swelling in 24h, Water Absorption in 2h, Water Absorption in 
24h, Internal Adhesion, Edge Screw Pullout and Face Screw Pullout. "CV” means Coefficient of variation (\%). 8, 10, 12 and 14\% are the four mass proportions of adhesive/particles considered.

Figure 2 - (a) Panel press device; and (b) Produced panel

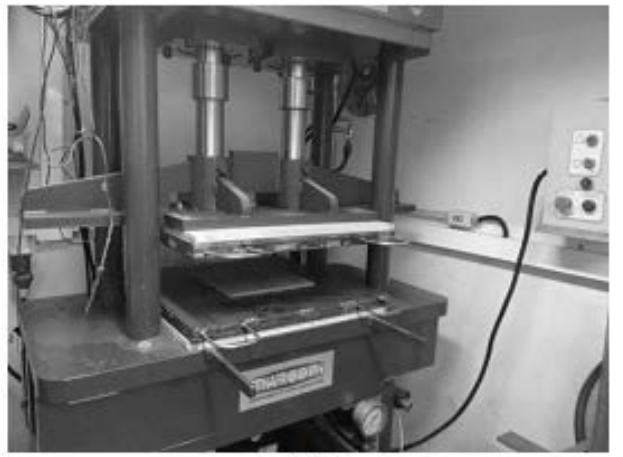

(a)

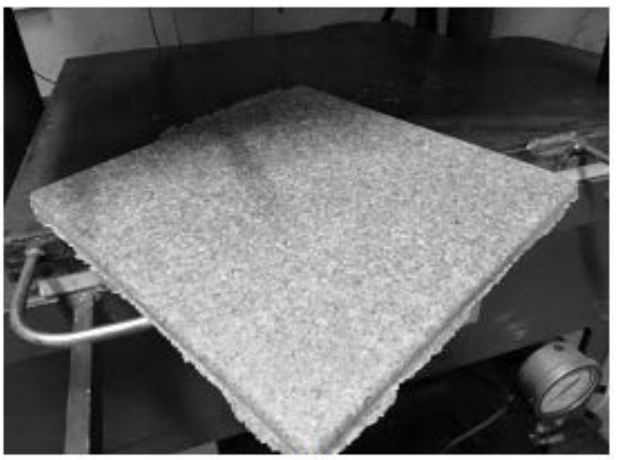

(b)

Table 2 - Summary of results for MOE and MOR

\begin{tabular}{c|c|c|c|c|c|c|c|c}
\hline \multirow{2}{*}{ Statistics } & \multicolumn{4}{|c}{ MOE (MPa) } & \multicolumn{4}{c}{ MOR (MPa) } \\
\cline { 2 - 9 } & $\mathbf{8 \%}$ & $\mathbf{1 0 \%}$ & $\mathbf{1 2 \%}$ & $\mathbf{1 4 \%}$ & $\mathbf{8 \%}$ & $\mathbf{1 0 \%}$ & $\mathbf{1 2 \%}$ & $\mathbf{1 4 \%}$ \\
\hline Average value & 2237.17 & 2423.95 & 2691.69 & 2679.77 & 16.66 & 20.11 & 21.59 & 22.36 \\
CV (\%) & 15.16 & 20.51 & 15.72 & 16.29 & 22.00 & 29.95 & 24.17 & 24.17 \\
Minimum & 1584.59 & 1753.96 & 2139.33 & 1544.69 & 10.69 & 12.63 & 15.40 & 9.98 \\
Maximum & 2768.17 & 3218.74 & 3549.67 & 3331.60 & 22.81 & 29.86 & 32.13 & 32.07 \\
Count & 15 & 15 & 15 & 15 & 15 & 15 & 15 & 15 \\
\hline
\end{tabular}

Table 3 - Summary of results for panel density and internal adhesion

\begin{tabular}{c|c|c|c|c|c|c|c|c}
\hline \multirow{2}{*}{ Statistics } & \multicolumn{4}{|c|}{ Density $\mathbf{( g / \mathbf { c m } ^ { \mathbf { 3 } } )}$} & \multicolumn{4}{c}{ Internal adhesion (MPa) } \\
\cline { 2 - 9 } & $\mathbf{8 \%}$ & $\mathbf{1 0 \%}$ & $\mathbf{1 2 \%}$ & $\mathbf{1 4 \%}$ & $\mathbf{8 \%}$ & $\mathbf{1 0 \%}$ & $\mathbf{1 2 \%}$ & $\mathbf{1 4 \%}$ \\
\hline Average value & 0.86 & 0.85 & 0.88 & 0.87 & 3.06 & 2.87 & 2.99 & 3.24 \\
CV (\%) & 4.11 & 3.92 & 4.44 & 3.98 & 19.97 & 32.38 & 33.44 & 25.02 \\
Minimum & 0.75 & 0.79 & 0.83 & 0.82 & 1.80 & 1.52 & 1.64 & 1.71 \\
Maximum & 0.90 & 0.89 & 0.94 & 0.92 & 3.96 & 4.36 & 5.35 & 4.60 \\
Count & 15 & 15 & 15 & 15 & 15 & 15 & 15 & 15 \\
\hline
\end{tabular}

Table 4 - Summary of results for thickness swelling in $\mathbf{2}$ and 24 hours

\begin{tabular}{c|c|c|c|c|c|c|c|c}
\hline \multirow{2}{*}{ Statistics } & \multicolumn{3}{|c|}{ Thickness swelling in 2h (\%) } & \multicolumn{3}{c}{ Thickness swelling in 24h (\%) } \\
\cline { 2 - 9 } & $\mathbf{8 \%}$ & $\mathbf{1 0 \%}$ & $\mathbf{1 2 \%}$ & $\mathbf{1 4 \%}$ & $\mathbf{8 \%}$ & $\mathbf{1 0 \%}$ & $\mathbf{1 2 \%}$ & $\mathbf{1 4 \%}$ \\
\hline Average value & 5.35 & 5.05 & 4.50 & 4.32 & 11.25 & 9.53 & 9.00 & 8.54 \\
CV (\%) & 14.53 & 19.85 & 24.54 & 15.40 & 7.95 & 8.91 & 10.12 & 6.84 \\
Minimum & 3.89 & 3.42 & 2.62 & 3.46 & 9.98 & 8.17 & 7.49 & 7.62 \\
Maximum & 6.75 & 6.80 & 6.70 & 5.66 & 12.77 & 11.07 & 10.59 & 9.54 \\
Count & 15 & 15 & 15 & 15 & 15 & 15 & 15 & 15 \\
\hline
\end{tabular}

Table 5 - Summary of results for water absorption in $\mathbf{2}$ and 24 hours

\begin{tabular}{c|c|c|c|c|c|c|c|c}
\hline \multirow{2}{*}{ Statistics } & \multicolumn{4}{|c|}{ Water absorption in 2h (\%) } & \multicolumn{3}{c}{ Water absorption in 24h (\%) } \\
\cline { 2 - 9 } & $\mathbf{8 \%}$ & $\mathbf{1 0 \%}$ & $\mathbf{1 2 \%}$ & $\mathbf{1 4 \%}$ & $\mathbf{8 \%}$ & $\mathbf{1 0 \%}$ & $\mathbf{1 2 \%}$ & $\mathbf{1 4 \%}$ \\
\hline Average value & 6.18 & 5.98 & 4.91 & 5.06 & 16.24 & 16.04 & 13.63 & 13.84 \\
CV (\%) & 15.71 & 26.40 & 16.55 & 27.34 & 12.61 & 23.72 & 12.65 & 16.91 \\
Minimum & 4.19 & 4.05 & 3.44 & 3.38 & 12.46 & 11.35 & 10.17 & 10.77 \\
Maximum & 7.87 & 10.08 & 6.22 & 8.66 & 19.45 & 23.55 & 16.36 & 18.58 \\
Count & 15 & 15 & 15 & 15 & 15 & 15 & 15 & 15 \\
\hline
\end{tabular}


Table 6 - Summary of results for Face and Edge screw pullout

\begin{tabular}{c|c|c|c|c|c|c|c|c}
\hline \multirow{2}{*}{ Statistics } & \multicolumn{4}{|c|}{ Face screw pullout (N) } & \multicolumn{3}{c}{ Edge screw pullout (N) } \\
\cline { 2 - 9 } & $\mathbf{8 \%}$ & $\mathbf{1 0 \%}$ & $\mathbf{1 2 \%}$ & $\mathbf{1 4 \%}$ & $\mathbf{8 \%}$ & $\mathbf{1 0 \%}$ & $\mathbf{1 2 \%}$ & $\mathbf{1 4 \%}$ \\
\hline Average value & 985.91 & 993.26 & 934.40 & 1017.79 & 1199.27 & 1427.36 & 1264.40 & 1304.73 \\
CV (\%) & 36.66 & 30.39 & 38.25 & 30.19 & 46.66 & 40.32 & 53.20 & 37.94 \\
Minimum & 441.45 & 637.65 & 294.30 & 441.45 & 343.35 & 392.40 & 245.25 & 490.50 \\
Maximum & 1471.50 & 1716.75 & 1520.55 & 1667.70 & 2550.60 & 2844.90 & 2893.95 & 2256.30 \\
Count & 15 & 15 & 15 & 15 & 15 & 15 & 15 & 15 \\
\hline
\end{tabular}

Table 2 shows that the increase of adhesive content makes the Modulus of Rupture of the standardized specimens under static bending tests greater. On the other hand, with $14 \%$ of adhesive content, the Modulus of elasticity seems remain unaltered compared to this mechanical property with $12 \%$ adhesive content. The Brazilian code prescribes that particleboards' lowest value of MOR is $18 \mathrm{MPa}$. Therefore, based on this information, only the panels produced with adhesive content greater than $8 \%$ met the normative specifications.

Table 3 presents Density and Internal adhesion results for the panels produced. The increase of adhesive content does not affect the panel densities, however the panels produced with $14 \%$ of adhesive content presented the greatest average value of Internal adhesion (the four compositions provided an average value of Internal adhesion greater them 0.4 MPa prescribed by the Brazilian code as the lowest value for this mechanical property).

Tables 4 and 5 present the results for thickness swelling in 2 and 24h, as well as the results for water absorption in 2 and 24h, which are the physical properties of the panels. These results indicate that the increase of adhesive content makes the thickness swelling and water absorption in 2 and 24 hours both smaller. All compositions provided a thickness swelling average value lower than $8 \%$, which is the standardized limit for this property according to the Brazilian code.

Table 6 shows the results for face and edge screw pullout tests for the four adhesive contents considered. The greatest value of face screw pullout force resulted from the panels produced with $14 \%$ of adhesive content, and the greatest value of edge screw pullout force resulted from the panels produced with $10 \%$ of adhesive content.

There are no similar investigations in the correlated literature, making the comparison of results found in this work with other correlated ones a difficult process. Nascimento et al. (2013) produced particleboards using Eucalyptus sp. and the castor oil-based polyurethane resin providing panel performances very similar to our findings in this investigation.

For comparison between panels produced with the four adhesive contents, ANOVA was performed at 5\% significance level for each one of the ten variables investigated. P-value greater than $5 \%$ leads to accept the hypothesis of equivalence of groups, refuting this hypothesis as an alternative one. Table 7 presents the ANOVA tests and the p-values for the validation tests ( $\mathrm{SW}$ and $\mathrm{Bt}$ ). The significative ANOVA p-values are underlined, meaning that these properties were influenced by the adhesive content variation. The “*” indicates that the logarithmic transformation was performed for the data.

Figures 3 to 5 present the boxplots of results for visual comparison of groups with significative p-value of ANOVA, i.e., the physical-mechanical properties that demonstrated performance modification with the adhesive content increase.

Tukey's contrast tests were performed at $5 \%$ significance level for the properties that presented significative p-values of ANOVA. Table 8 presents the summary of the contrast test, where "a" is greater than " $b$ " that is greater than "c".

As shown in Figures 3 to 5 and Table 8, the increase of adhesive content caused the increase of MOE and MOR average values. In addition, the greater the adhesive content the smaller the thickness swelling and water absorption of up to $12 \%$ of adhesive content, and above this percentage of adhesive content, the physical and mechanical properties remain unaltered. 
Table 7 - ANOVA results

\begin{tabular}{c|c|c|c|c|c|c|c}
\hline & DF & SS & MS & F & p-value & $\begin{array}{c}\text { SW } \\
\text { p-value }\end{array}$ & $\begin{array}{c}\text { Bt } \\
\text { p-value }\end{array}$ \\
\hline Density treat. & 3 & 0.00883 & 0.00294 & 2.313 & 0.0858 & 0.3932 & 0.9423 \\
\hline Residuals & 56 & 0.07127 & 0.00127 & & & & \\
\hline MOE treat. & 3 & 2154966 & 718322 & 3.926 & $\underline{0.0130}$ & 0.9055 & 0.5821 \\
\hline Residuals & 56 & 10246391 & 182971 & & & & \\
\hline MOR treat. & 3 & 287.4 & 95.8 & 3.61 & $\underline{0.0187}$ & 0.1603 & 0.3400 \\
\hline Residuals & 56 & 1486.2 & 26.54 & & & & \\
\hline Int. adhesion treat. & 3 & 1.08 & 0.3588 & 0.495 & 0.6870 & 0.6262 & 0.3200 \\
\hline Residuals & 56 & 40.6 & 0.7251 & & & & \\
\hline Thick.Swel.-2h treat. & 3 & 10.3 & 3.434 & 4.194 & $\underline{0.0095}$ & 0.2903 & 0.2393 \\
\hline Residuals & 56 & 45.84 & 0.819 & & & & \\
\hline Thick.Swel.-24h treat.* & 3 & 0.12128 & 0.04043 & 29.43 & $\underline{0.0000}$ & 0.1586 & 0.5482 \\
\hline Residuals & 56 & 0.07692 & 0.00137 & & & & \\
\hline Water absorp.-2h treat. $*$ & 3 & 0.1178 & 0.03928 & 4.585 & $\underline{0.0061}$ & 0.8970 & 0.2441 \\
\hline Residuals & 56 & 0.4797 & 0.00857 & & & & \\
\hline Water absorp.-24h treat. & 3 & 87.4 & 29.131 & 4.298 & $\underline{0.0085}$ & 0.0795 & 0.0561 \\
\hline Residuals & 56 & 379.5 & 6.777 & & & & \\
\hline Face S. P. $\sim$ treat. & 3 & 73711 & 24570 & 0.221 & 0.8810 & 0.3364 & 0.7957 \\
\hline Residuals & 56 & 8435696 & 110996 & & & & \\
\hline Edge S. P. $\sim$ treat. & 3 & 553011 & 184337 & 0.55 & 0.6500 & 0.1656 & 0.6159 \\
\hline Residuals & 56 & 25494771 & 335458 & & & & \\
\hline
\end{tabular}

Figure 3 - Boxplots of (a) MOE and (b) MOR

MOE (MPa)

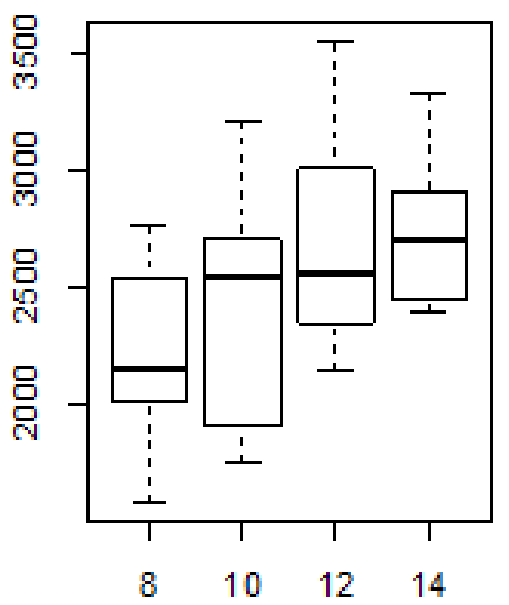

Tre atm ents

(a)
MOR (MPa)

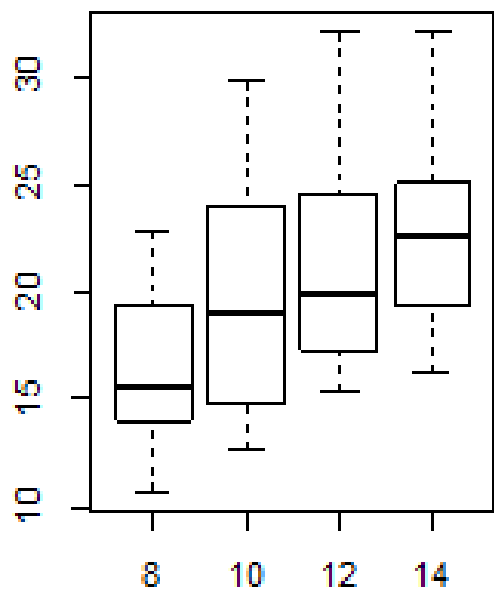

Treatments

(b) 
Figure 4 - Boxplots of (a) Thickness Swelling - $2 \mathrm{~h}$ and (b) Thickness Swelling - 24h

\section{Thickness Swelling - $2 \mathrm{~h}(\%)$}

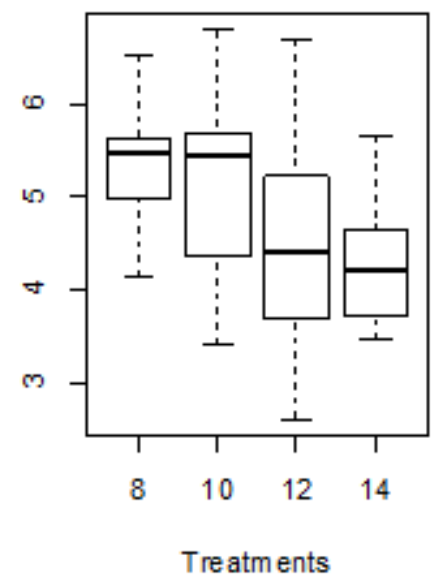

(a)
Thickness Swelling - 24h (\%)

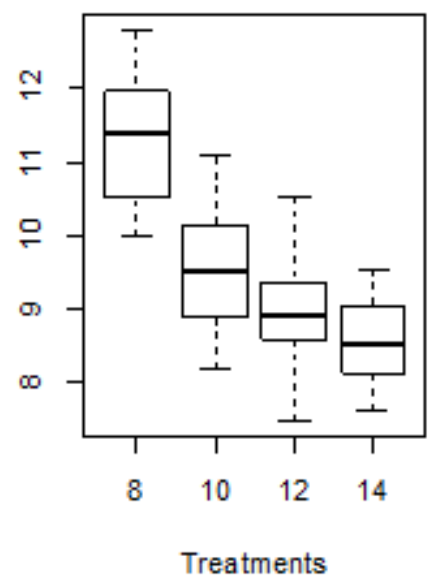

(b)

Figure 5 - Boxplots of (a) Water absorption - $2 \mathrm{~h}$ and (b) Water absorption - 24h

Water absorption - $2 \mathrm{~h}(\%)$

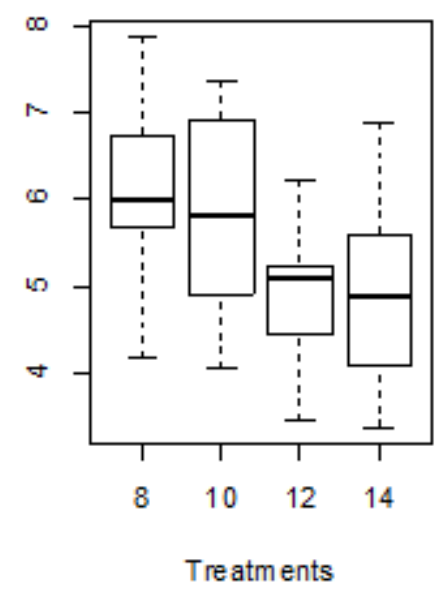

Water absorption - 24h (\%)

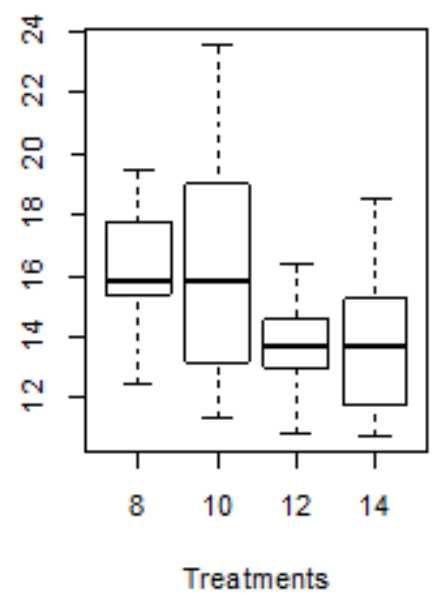

Table 8 - Tukey`s contrast tests

\begin{tabular}{c|c|c|c|c}
\hline \multirow{2}{*}{ Panels properties } & \multicolumn{4}{|c}{ Treatments } \\
\cline { 2 - 5 } & $\mathbf{8 \%}$ & $\mathbf{1 0 \%}$ & $\mathbf{1 2 \%}$ & $\mathbf{1 4 \%}$ \\
\hline MOE & $\mathrm{b}$ & $\mathrm{ab}$ & $\mathrm{a}$ & $\mathrm{a}$ \\
MOR & $\mathrm{b}$ & $\mathrm{ab}$ & $\mathrm{a}$ & $\mathrm{a}$ \\
Thickness swelling in 2h & $\mathrm{a}$ & $\mathrm{ab}$ & $\mathrm{ab}$ & $\mathrm{b}$ \\
Thickness swelling in 24h & $\mathrm{a}$ & $\mathrm{b}$ & $\mathrm{bc}$ & $\mathrm{c}$ \\
Water absorption in 2h & $\mathrm{a}$ & $\mathrm{ab}$ & $\mathrm{b}$ & $\mathrm{b}$ \\
Water absorption in 24h & $\mathrm{a}$ & $\mathrm{ab}$ & $\mathrm{b}$ & $\mathrm{ab}$ \\
\hline
\end{tabular}

\section{Conclusion}

The increase of adhesive content caused an increase of MOR, but the MOE and the physical properties remained unaltered above $12 \%$ of adhesive content. Adhesive content greater than $8 \%$ provided panel performances that met the standardized specifications. Based on these results it is possible to conclude that waste of glulam produced with Eucalyptus urograndis and polyurethane resin can be used as raw material for particleboard production. 


\section{References}

ALMEIDA, D. H. et al. Analysis of solid waste generation in a wood processing machine. International Journal of Agriculture and Forestry, v. 7, n. 3, p. 76-79, 2017.

ALMEIDA, D. H. et al. Evaluation of quality in the adhesion of glued laminated timber (Glulam) of Paricá and Lyptuswood species. International Journal of Materials Engineering, v. 4, p. 114-118, 2014.

ALVES, L. S. et al. Particleboard produced with sawmill waste of different wood species. Advanced Materials Research, v. 884, p. 689-693, 2014.

ASSOCIAÇÃO BRASILEIRA DE NORMAS TÉCNICAS. NBR 14810: chapas de madeira aglomerada: parte 2: requisitos. Rio de Janeiro, 2006b.

ASSOCIAÇÃO BRASILEIRA DE NORMAS TÉCNICAS. NBR 14810: chapas de madeira aglomerada: parte 3: métodos de ensaio. Rio de Janeiro, 2006a.

BIAZUS, A.; HORA, A. B.; LEITE, B. G. P. Panorama de mercado: painéis de madeira, v. 32, p. 49-90, 2010.

FERRO, F. S. et al. Mechanical properties of particleboards manufactured with Schizolobiumamazonicum and castor oil based polyurethane resin: Influence of proportion polyol/pre-polymer. International Journal of Composite Materials, v. 4, n. 2, p. 52-55, 2014.

FIORELLI, J. et al. Painéis de Partículas Com Resíduos de Madeira de Reflorestamento. Acta Scientiarum, v. 36, n. 2, p. 251-256, 2014.

FOREST PRODUCTS LABORATORY. Wood handbook: wood as an engineering material. USDA Agriculture Handbook, No. 72, 1999 (Forest Products Laboratory, Madison, WI).

ICIMOTO, F. H. et al. Influence of lamellar thickness on strength and stiffness of glued laminated timber beams of Pinus oocarpa. International Journal of Materials Engineering, v. 6, n. 2, p. 51-55, 2016.

ICIMOTO, F. H. Glulam sleepers reinforced with fiber glass fabric. São Carlos, 2018. 105 f. PhD Thesis - Engineering School of São Carlos, University of São Paulo, São Carlos, 2018.

IWAKIRI, S. Painéis de madeira reconstituída. Curitiba: Fupef, 2005.

LESSMANN, V. E. Estudo da reação de cura de resinas Uréia-formol por Espectrometria de Ressonância Magnética Nuclear. Curitiba, 2008. Dissertação (Mestrado em Química) - Programa de PósGraduação em Química, Universidade Federal do Paraná, Curitiba, 2008.

MENDES, R. F. et al. Particleboards produced with sugar cane bagasse and Eucalyptus wood. Scientia Forestalis, v. 38, n. 86, p. 285-295, 2010.

MIRZAEI, G.; MOHEBBY, B.; EBRAHIMI, G. Glulam beam made from hydrothermally treated poplar wood with reduced moisture induced stresses. Construction and Building Materials, 135,386-393, 2017.

NASCIMENTO, M. F. et al. Viabilidade do emprego de Eucalyptus tratado com CCA e CCB na produção de painéis particulados de alta densidade. In: PAINÉIS de partículas. São Carlos: EESC/USP, 2013.

OGUNWUSI, A. A. Wood waste generation in the forest industry in Nigeria and prospects for its industrial utilization. Civil and Environmental Research, v. 16, n. 9, p. 62-69, 2014.

OSMANNEZHAD, S.; FAEZIPOUR, M.; EBRAHIMI, G. Effects of GFRP on bending strength of glulam made of poplar (Populus deltoids) and beech (Fagus orientalis). Construction and Building Materials, v. 51, p. 34-39, 2014.

SEGUNDINHO, P. G. A. et al. Evaluation of Brazilian reforestation species in glulam beams before and after preservative chemical treatments. International Journal of Materials Engineering, v. 4, p. 192-195, 2014.

ZHOU, H. Z.; ZHU, E. C.; TORATTI, T. Modelling the hygrothermal stress in curved glulam beams. The Journal of Strain Analysis for Engineering Design, v. 45, n. 2, p. 129-140, 2009. 


\section{Acknowledgments}

The authors thank CAPES for the financial support (this study was financed by the Coordenação de Aperfeiçoamento de Pessoal de Nível Superior - Brasil (CAPES) - Finance Code 001), Wood and Timber Structures Laboratory (LaMEM) of the Department of Structural Engineering (SET) of the São Carlos Engineering School (EESC) - University of São Paulo (USP).

\section{Tiago Hendrigo de Almeida}

Departamento de Ciências e Engenharia de Materiais | Universidade de São Paulo | Av. Trabalhador Saocarlense,400, Parque Arnold Schimidt | São Carlos - SP - Brasil | CEP13566-590 | Tel.: (16) 3373-9483 | E-mail: tiago.hendrigo@gmail.com

\section{Fabiane Salles Ferro}

Departamento de Engenharia Florestal | Universidade Estadual do Centro-Oeste | Rua Maria Rosa Zanon de Almeida | Irati - PR - Brasil | CEP 84505-677| Tel.: (42) 3421-3000 | E-mail: fabi.salles. ferro@gmail.com

\section{Diego Henrique de Almeida}

Departamento de Engenharia Civil | Universidade Federal de Rondônia | BR 364-km 9,5 | Porto Velho - RO - Brasil | CEP 76801-059 | E-mail: diegoestruturas@gmail.com

\section{Francisco Antonio Rocco Lahr}

Departamento de Engenharia de Estruturas | Universidade de São Paulo | E-mail: frocco@sc.usp.br

\section{Ambiente Construído}

Revista da Associação Nacional de Tecnologia do Ambiente Construído

Av. Osvaldo Aranha, 99 - 3ㅇ andar, Centro

Porto Alegre - RS - Brasil

CEP 90035-190

Telefone: +55 (51) 3308-4084

Fax: +55 (51) 3308-4054

www. seer. ufrgs. br/ ambienteconstruido

E-mail: ambienteconstruido@ufrgs.br 